\title{
What Are the Odds? Option-Based Forecasts of FOMC Target Changes
}

\author{
William R. Emmons, Aeimit K. Lakdawala, and Christopher J. Neely
}

\begin{abstract}
This article uses probability forecasts derived from options to assess evolving market uncertainty about Federal Reserve monetary policy actions in a variety of recent events and episodes. Options on federal funds futures contracts reveal a complete probability density function over possible Federal Reserve target rates, thus augmenting the expectations provided by federal funds futures contracts. Option-based forecasts are most useful when more than two federal funds target outcomes are plausible at an upcoming policy meeting. (JEL E47, E52, G13)
\end{abstract}

Federal Reserve Bank of St. Louis Review, November/December 2006, 88(6), pp. 543-61.

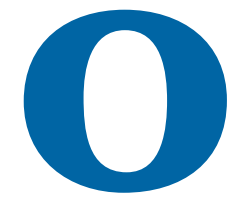

ptions on federal funds futures contracts provide information about market expectations of Federal Open Market Committee (FOMC) monetary policy actions above and beyond that provided by federal funds futures contracts alone. In particular, options provide important information about the dispersion and skewness of market expectations. Under some assumptions, option prices imply a complete probability density function (PDF) over possible FOMC target-rate choices.

This article uses the method of Carlson, Craig, and Melick (2005) to extract an implied riskneutral probability density function over possible future federal funds target rates from daily option prices. Option-based forecasts are most useful when more than two federal funds target outcomes are plausible at an upcoming FOMC meeting. If only one or two meeting outcomes are plausible, a futures-based forecast is simpler and more appropriate.

\section{FEDERAL FUNDS FUTURES OPTIONS}

The Chicago Board of Trade has offered futures contracts written on the federal funds rate since 1988. For more than a decade, trading volumes in these contracts remained miniscule in comparison with other interest rate futures contracts, such as 3-month eurodollar and long-term Treasury securities. Researchers nonetheless have found that federal funds futures contracts provide useful information about market expectations of shortterm interest rate movements (Poole, Rasche, and Thornton, 2002; Sack, 2004; and Piazzesi and Swanson, 2005).

For reasons that are not well understood, trading volumes in the federal funds futures contracts increased dramatically after 2000. ${ }^{1}$ This led to the introduction, in 2003, of exchange-traded

\footnotetext{
1 See Carlson, Craig, and Melick (2005) for a more extensive discussion of federal funds futures options contracts and market conventions. The Chicago Board of Trade provides contract specifications and current market prices for both federal funds futures and futures options at

www.cbot.com/cbot/pub/cont_detail/0,3206,1525+14453,00.html.
}

William R. Emmons is a senior economist, Aeimit K. Lakdawala was a research associate at the time this article was written, and Christopher J. Neely is a research officer at the Federal Reserve Bank of St. Louis.

(C) 2006, The Federal Reserve Bank of St. Louis. Articles may be reprinted, reproduced, published, distributed, displayed, and transmitted in their entirety if copyright notice, author name(s), and full citation are included. Abstracts, synopses, and other derivative works may be made only with prior written permission of the Federal Reserve Bank of St. Louis. 


\section{THE FEDERAL FUNDS FUTURES AND OPTIONS-ON-FUTURES MARKETS}

The 30-day federal fund futures contract is an interest rate derivative, which has been traded on the Chicago Board of Trade since October 3, 1988. The volume of trading on federal funds has grown dramatically since the market's inception, reaching almost 6.3 million contracts traded in 2002. Prices on the federal funds futures markets are quoted as 100 minus the average daily federal funds overnight rate for the delivery month. That is, a price quote of $96.1 \mathrm{implies}$ an average daily interest rate of $(100-96.1=) 3.9$ percent for the delivery month.

Contracts are settled in cash, at 2:00 p.m. central time, on the last trading day of the month. The final settlement price for the contract is the average daily federal funds overnight rate for the delivery month, as reported by the Federal Reserve Bank of New York. The average is calculated over calendar days. The notional contract size is $\$ 5$ million, which means that a rise in the contract price of 1 basis point nets (costs) a holder of a long (short) position $\$ 41.67$. The $\$ 41.67$ is the increase in the interest earned from a 1-basis-point rise in interest rates on a deposit held for 30 days, using a day count of 360 days per year $(41.67=5,000,000 * 0.0001 * 30 / 360)$. The minimum quote size is one-half of 1 basis point.

The Chicago Board of Trade has sponsored trading American options on federal funds futures contracts since March 14, 2003. ${ }^{1}$ Strike prices are created every 6.25 basis points. The asset underlying the options contract is one federal funds futures contract. Option premia are quoted in basis points and the minimum tick size is one-quarter of 1 basis point or $\$ 10.4175$. Options contracts trade until the last business day of the delivery month.

Because other short-term interest rates closely track the federal funds rate, federal funds futures can be used to hedge general short-term interest rate risk and/or speculate on future short-term interest rates. And the design of the options on federal funds futures permits speculators to invest based on detailed views on the likely path of the future funds rate. Therefore a variety of users find federal funds futures and options on federal funds futures to be useful. Users of options on federal funds futures include issuers of commercial paper, portfolio managers, dealers in government securities, hedge fund managers, and even foreign exchange dealers.

1 American options can be exercised any time until expiry; European options can be exercised only at expiry.

options contracts written on federal funds futures contracts. A federal funds futures call option, for example, gives the buyer the right, but not the obligation, to obtain a long position in the referenced federal funds futures contract at a prespecified price. The options are American-style (i.e., they can be exercised at any time up to or at maturity) and are settled in cash rather than by actual delivery of the futures contract. Trading volume in federal funds futures options has varied considerably over time, but substantial amounts of open interest have been observed in some contracts. The first boxed insert, on the federal funds futures and options-on-futures markets, reviews the specifications of those derivative contracts.

Finance theory long has recognized that a rich set of option contracts written on any underlying financial instrument or economic variable, such as an interest rate (or interest rate futures contract), can provide a great deal of information beyond simple expectations of a future price. In particular, option prices reveal how much investors are willing to pay for a chance to profit from an "extreme" future movement in the spot price of the reference instrument, either up or down. Therefore, option prices can potentially tell 
us about investors' expectations, including how likely "extreme" movements are thought to be.

Changes in estimated probability density functions over time illuminate how market uncertainty about Federal Reserve monetary policy intentions or actions evolved during significant episodes or events during the period June 2003 through April 2006. ${ }^{2}$ The events we study are as follows:

- A pre-commitment to extended policy accommodation: In August 2003, the Federal Reserve publicly committed itself to maintaining monetary policy accommodation for a "considerable period."

- A signal of an impending target change: In May 2004, the Federal Reserve signaled that its first target-rate increase in four years was forthcoming.

- A pre-commitment to gradual removal of policy accommodation: Beginning in June 2004, the Federal Reserve publicly committed itself to a policy of raising the federal funds target rate at a "measured pace."

- Devastating hurricanes: In August and September 2005, a series of hurricanes devastated parts of the U.S. Gulf Coast, creating uncertainty about their economic impacts and the Federal Reserve's likely response.

- Congressional testimony and public communication: Reports of Chairman Bernanke's April 2006 testimony before the Joint Economic Committee whipsawed financial markets.

In each case, we study the federal funds futures option-implied probabilities assigned by market participants to possible Federal Reserve target-rate choices at upcoming meetings. In the first and third cases listed above, our data allow us to evaluate the (evolving) credibility of Federal Reserve commitments to future actions. The second and fourth cases are examples of market uncertainty about both economic fundamentals

2 In related research, Neely (2005) relates surprises in federal funds target changes to large changes in the implied volatility of 3-month eurodollar rates. and the Federal Reserve's likely reactions to these fundamentals. Finally, the last case clearly illustrates pronounced market reactions to Federal Reserve communication efforts.

The remainder of the article is organized as follows. The next section briefly discusses federal funds futures contracts as market-based indicators of expected monetary policy actions. Then, we describe option contracts on federal funds futures and explain how one can extract probability density functions over future Federal Reserve targetrate choices from such option prices. Finally, we use daily option-derived risk-neutral probability density functions to explore the evolution of market uncertainty about future interest rates during several recent episodes.

\section{FEDERAL FUNDS FUTURES CONTRACTS AND EXPECTED MONETARY POLICY ACTIONS}

Figure 1 displays the implied federal funds rate from the futures contract closest to expiration (heavy black line), as well as the implied average rate on every third federal funds rate futures contract traded between May 1, 2003, and February 9, 2006 (all other lines). Several futures contracts trade on any given day, each written on a different future month. For example, 12 different futures contracts traded on December 2, 2005-one referring to each month from December 2005 through November 2006. Figure 1 shows only those from December 2005 and March, June, and September 2006.

The final settlement price on each month's contract depends on the average effective daily federal funds rate during that contract month. That is, the December 2005 settlement price was 95.84, calculated as 100 minus the 30-day average of actual effective federal funds rates observed during December 2005, which was 4.16 percent. As each contract trades over time-until settlement on the first business day after the end of the contract month-the market price converges toward the final settlement price. The figure illustrates that the volatility of futures prices varies over time, indicating that uncertainty about future interest rates likewise varies. Note that, while 


\section{Figure 1}

\section{Daily Federal Funds Target Rate and Futures-Implied Yields Between May 1, 2003, and February 9, 2006}

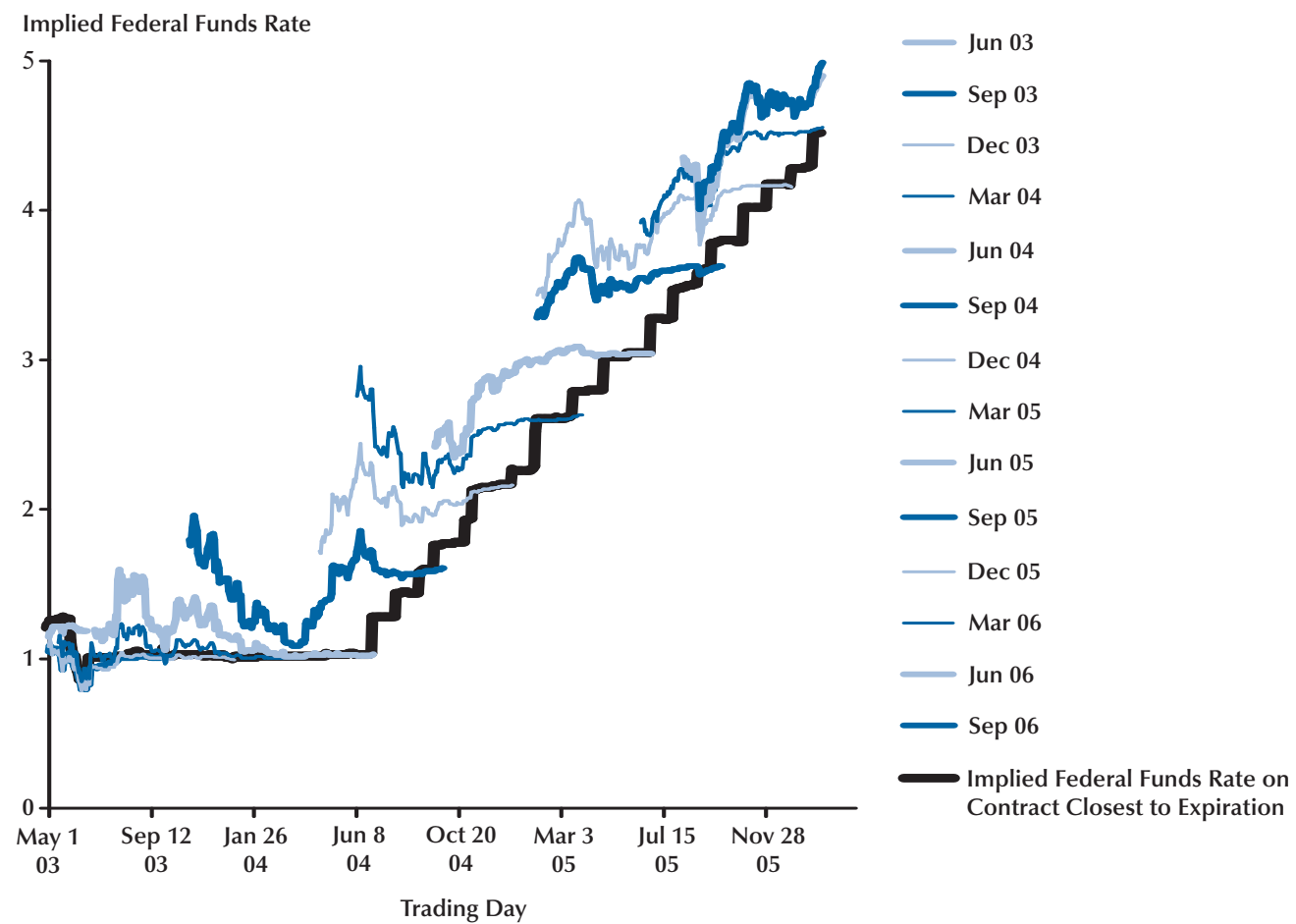

NOTE: The thick black line is the implied federal funds rate from the contract closest to expiration. The other lines represent implied yields from daily settlement of federal funds futures contracts traded between May 1, 2003, and February 9, 2006.

uncertainty (volatility) about a particular contract's settlement price decreases over time, the decline in uncertainty is not monotonic.

Federal funds futures contracts usefully gauge market expectations about future FOMC monetary policy actions, although there are more sophisticated approaches to forecasting rate changes and levels (e.g., Sarno, Thornton, and Valente, 2005). There is some evidence that econometric models may improve on the implied forecasts from futures prices, particularly at long horizons, where risk premia might be larger and futures trading volume is much lower.

Expected federal funds targets derived from federal funds futures contracts represent only the central tendency (the mean) of market expectations, not the dispersion of expectations about potential outcomes. Dispersion of expectations increases with the forecast horizon. The next section explains how options on short-dated money-market instruments inform us about expected volatility (uncertainty), the direction of risks (asymmetry), and the relative probability of extreme events (kurtosis). One can interpret the dispersion of expectations as measuring the public's uncertainty about monetary policy.

\section{OPTIONS ON FEDERAL FUNDS FUTURES CONTRACTS}

Option contracts written on federal funds futures contracts provide a tool to measure (and speculate on) the uncertainty among market participants about future monetary policy actions. 
The Bank of England has used the information contained in option prices for informational purposes for some time, and other central banks may follow.

There is a large academic literature that uses market data to forecast interest rates. Recent examples using data from the federal funds futures market to forecast future Federal Reserve policy actions include Poole, Rasche, and Thornton (2002), Sack (2004), and Piazzesi and Swanson (2005). Another strand of the literature investigates the use of options on interest rate futures contracts to assess market expectations of future short-term interest rates. Papers investigating option-based forecasts include Abken (1995), Soderlind and Svensson (1997), Bliss and Panigirtzoglou (2002), Andersen and Wagener (2002), Hordahl and Vestin (2005), and Carlson, Craig, and Melick (2005). This article builds on the option-based forecasting research pioneered in these papers.

\section{How Liquid Are Federal Funds Futures and Futures Options?}

Although one would like to estimate expectations of federal funds rate targets for the indefinite future, futures and futures-option contracts do not have sufficient liquidity to derive expectations more than a few months ahead. Figure 2 shows trading volume and open interest (log scale, by forecast horizon) for futures and options on futures for trading days in November 2005. The greatest trading volume occurs in options on futures contracts expiring 1 to 3 months in the future; there is still non-negligible volume in options 4 to 5 months ahead and practically no volume more than 6 months ahead. The open interest charts tell a similar story. Open interest falls off from 3 to 4 months and then to very low levels at 6 months.

Thus, futures and options on futures may not be very informative at long horizons. Note, however, that the trading volume and open interest in options-which include all strike prices-are much greater than that in the underlying futures contract. Fluctuations in trading volume over longer periods appear to indicate that trading increases during turbulent periods, precisely when information is most needed.

\section{Probability Densities Over the Federal Funds Target Rate}

The payoffs to options on federal funds futures depend only on the average federal funds rate over the contract expiration month. Therefore, the price of the option provides some information on the likelihood of various outcomes. For example, if the price of a given call option rises, then-all else equal-the market expects a greater probability of a higher final settlement price (a lower interest rate).

To translate option prices into risk-neutral probabilities of specific outcomes, however, one must make some assumption about the risk premia that investors require (or are willing to pay) to take certain risks. Carlson, Craig, and Melick (2005) compare the task of obtaining probabilities from option prices to estimating the probability of a fire from the price of fire insurance. If fire insurance companies demand a risk premium to insure houses, then one must know this premium to accurately estimate the probability of a fire from the price of insurance and the firm's contingent liability.

Similarly, to infer the probability density function over possible federal funds target rates from option prices, one must make some assumptions about risk premia embedded in federal funds futures prices. One hypothesis is that the marginal investors (buyers and sellers) are risk-neutral (i.e., that observed prices are actuarially fair). However, Hordahl and Vestin (2005), among others, find evidence of important differences between riskneutral and objective (i.e., realized) probability distributions in bond prices.

In general, it is not clear whether these discrepancies represent risk premia in the economic sense of compensation for risk. Piazzesi and Swanson (2005) document substantial prediction biases in federal funds futures prices and label them risk premia. Table 1, excerpted from Piazzesi and Swanson (2005), shows the estimates of the difference between futures-rate predictions and realized interest rates $n$ months ahead. The estimated regression is as follows:

$$
f_{t}^{n}-r_{t+n}=\alpha^{(n)}+\varepsilon_{t+n}^{n},
$$


Figure 2

\section{Trading Volumes and Open Interest on Federal Funds Futures and Futures Options During November 2005}
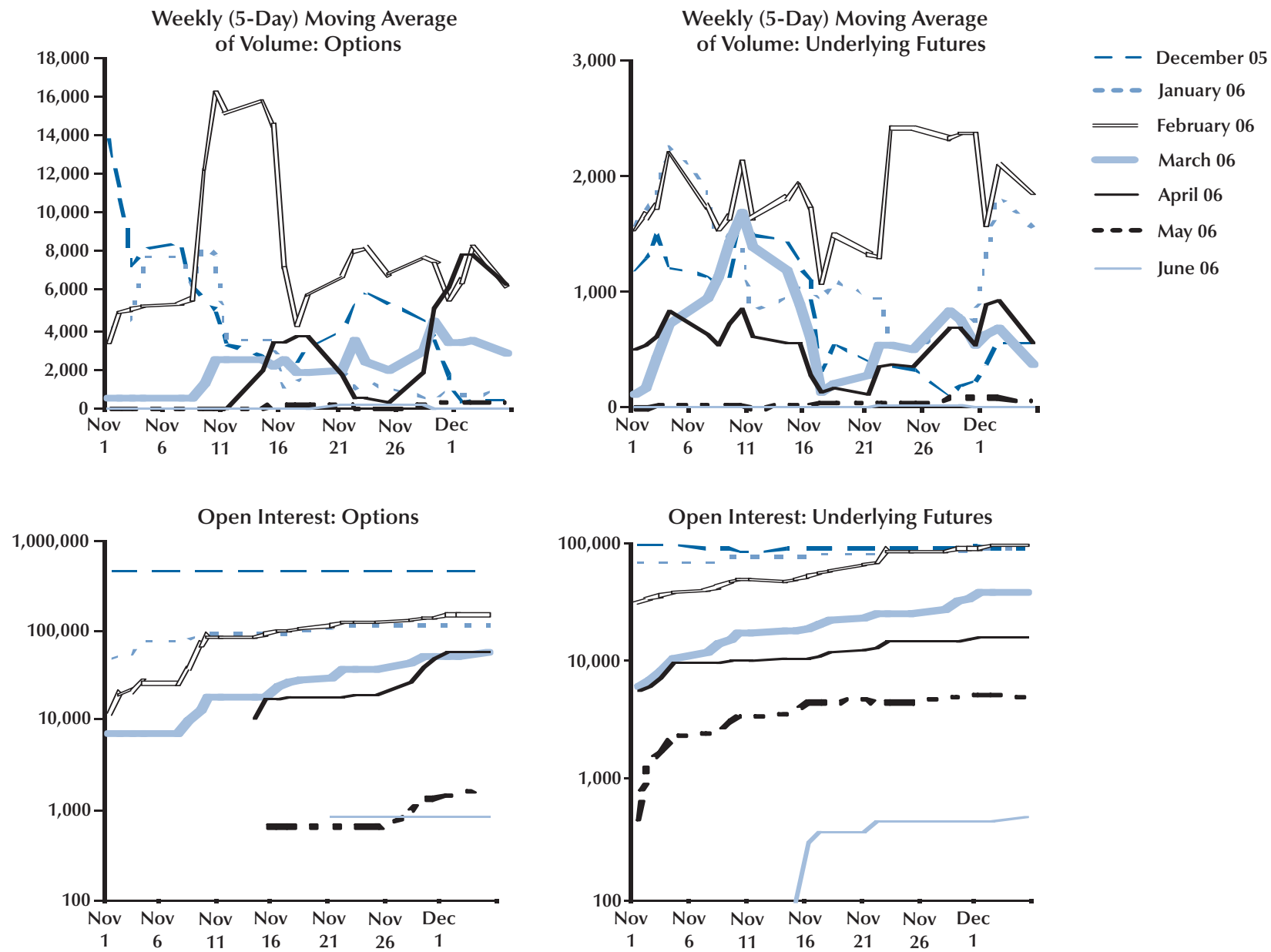

NOTE: The figure displays open interest (lower panels) and trading volumes (upper panels) from federal funds futures contracts (right panel) and option contracts (left panel) in November 2005. The vertical scales for the lower panels are in logarithmic form.

where $f_{t}^{n}$ is the $n$-period-ahead interest rate implied by the federal funds futures price in month $t$ and $r_{t+n}$ is the actual (realized, ex post) average funds rate in month $t+n$, to which the federal funds futures price should converge. Thus, the value of $\alpha^{(n)}$ in the table corresponding to the 1-month horizon (3.4) indicates that the futuresimplied forecast of the interest rate exceeds the realized 1-month-ahead interest rate by 3.4 basis points, on average.
Table 1 indicates that the forecasted federal funds rate exceeds the actual rate by 3 to 6 basis points per month of the forecast horizon. At a 6month horizon, Piazzesi and Swanson estimate a 73-basis-point risk premium on an annualized basis. This appears implausibly large to Carlson, Craig, and Melick (2005), who point out that one observes only a prediction bias; its meaning is unclear. For this reason, they assume no risk premium at all. 


\section{Table 1}

Piazzesi and Swanson (2005) Estimates of Federal Funds Futures Risk Premia

\begin{tabular}{lcccccc}
$\boldsymbol{n}$ & $\mathbf{1}$ & $\mathbf{2}$ & $\mathbf{3}$ & $\mathbf{4}$ & $\mathbf{5}$ & $\mathbf{6}$ \\
\hline$\alpha^{(n)}$ & 3.4 & 7.4 & 12.5 & 19.2 & 27.6 & 36.7 \\
$(t$-statistic $)$ & $(3.9)$ & $(3.6)$ & $(3.2)$ & $(3.2)$ & $(3.2)$ & $(3.1)$ \\
Annualized & 41.2 & 44.6 & 49.9 & 57.6 & 66.3 & 73.4
\end{tabular}

NOTE: The table is excerpted from Piazzesi and Swanson (2005). The table shows results from regressing the difference between the implied average federal funds rate, $n$ months ahead, on the realized federal funds rate for that month, from 1988:10 to 2003:12: $f_{t}^{n}-r_{t+n}=\alpha^{(n)}+\varepsilon_{t+n}^{(n)}$. Standard errors are heteroskedastic and autocorrelation consistent; $t$-statistics from those standard errors are in parentheses; $\alpha^{(n)}$ is measured in basis points.

Although we are uncertain about the existence and magnitude of risk premia in futures prices, we think that it is reasonable to assume that the prediction bias is 1 basis point per month in the empirical work that follows. For our purposes in illustrating broad movements of market expectations over time, the precise nature of our riskpremium assumption is not critical. The second boxed insert, on risk premia versus term premia, discusses whether one should interpret any observed prediction bias in the federal funds futures market as a term premium, a common interpretation of a risk premium in fixed-income markets.

In addition to a risk premium in the level of the futures price, there might be significant risk premia associated with exposure to option-price changes caused by changing volatility. Such premia are more difficult to estimate, although some researchers have begun to do so. Nevertheless, even in the presence of constant but unknown risk premia, changes in estimated PDFs still presumably tell us about changes in the true, physical density.

\section{Estimating Federal Funds Target Probability Densities}

Densities for asset prices (or interest rates) have been derived under a variety of assumptions about the functional form of the distribution. For asset prices that take continuous values, such as equities or foreign exchange, estimating densities quickly becomes very complicated and technical. Fortunately, the fact that the federal funds target rate historically has taken on a discrete set of values-in multiples of 25 basis points since 1989-greatly simplifies its estimation.

Consider a scenario in which the Fed is certain to choose from only three possible target rates, $\left\{T_{1}, T_{2}\right.$, and $\left.T_{3}\right\}$. Each of these three targets implies a unique average federal funds rate $\left\{F_{T, 1}, F_{T, 2}\right.$, and $\left.F_{T, 3}\right\}$ for the month of the FOMC meeting if the target is known to change only on the date of the FOMC meeting, day N. Given an initial value for the federal funds target at the start of the month, $T_{0}$, and a given target, $T_{1}$ (set at the FOMC meeting), one can solve for the average federal funds rate, $F_{T, 1}$, that $T_{1}$ implies, as follows:

$$
F_{T, 1}=T_{0} N / 30+T_{1}(30-N) / 30 .
$$

If three options, with strike prices $X_{1}, X_{2}$, and $X_{3}$, are actively traded on a given day, where $X_{1}$ is the strike on a call and $X_{2}$ and $X_{3}$ are the strikes on puts, then the probability of the selection of each target can be estimated using the following regression:

\section{(3)}

$$
\begin{aligned}
& {\left[\begin{array}{l}
e^{r(T-t)} C\left(t, T, X_{1}, F_{t}\right) \\
e^{r(T-t)} P\left(t, T, X_{2}, F_{t}\right) \\
e^{r(T-t)} P\left(t, T, X_{3}, F_{t}\right)
\end{array}\right]=} \\
& {\left[\begin{array}{lll}
\max \left(0, F_{T, 1}-X_{1}\right) & \max \left(0, F_{T, 2}-X_{1}\right) & \max \left(0, F_{T, 3}-X_{1}\right) \\
\max \left(0, X_{2}-F_{T, 1}\right) & \max \left(0, X_{2}-F_{T, 2}\right) & \max \left(0, X_{2}-F_{T, 3}\right) \\
\max \left(0, X_{3}-F_{T, 1}\right) & \max \left(0, X_{3}-F_{T, 2}\right) & \max \left(0, X_{3}-F_{T, 3}\right)
\end{array}\right]\left[\begin{array}{c}
\pi_{1} \\
\pi_{2} \\
\pi_{3}
\end{array}\right]+\left[\begin{array}{c}
\varepsilon_{t, 1} \\
\varepsilon_{t, 2} \\
\varepsilon_{t, 3}
\end{array}\right],}
\end{aligned}
$$

where the variables on the left-hand side are the riskless values of the current option prices at expiry and the explanatory variables are the payoffs to the options under the three states of the 


\section{RISK PREMIA VERSUS TERM PREMIA IN THE FEDERAL FUNDS FUTURES MARKET}

Futures prices of non-storable commodities embody only market expectations of future supply and demand conditions. Non-storable commodities are perishables-things that cannot be set aside and carried into future periods. Fresh eggs, for example, are non-storable because they spoil quickly and cannot be frozen or otherwise preserved.

Federal funds futures prices reflect the value today of a future claim on deposit balances at the Federal Reserve (reserves). Reserves are non-storable because a bank cannot hold reserves today to satisfy future reserve requirements. Thus, today's federal funds futures prices reflect market expectations of future reserve-market conditions. In other words, they are an indicator of future Federal Reserve monetary policy actions.

There could be a market-risk or liquidity premium associated with trading of federal funds futures contracts because their expected returns co-vary with other returns and because this market is not perfectly liquid. However, any such premium should not be thought of as a traditional term premium. Because every future period's reserve-market conditions are independent of all previous period's conditions-that is, there is no possible riskless arbitrage between them-we would not expect any systematic relationship between a futures price and the contract's term to maturity (i.e., a term premium).

world (possible FOMC target-rate choices). ${ }^{3}$ The coefficients $\left\{\pi_{1}, \pi_{2}, \pi_{3}\right\}$ are the probabilities that set the expected payoffs of the options (right-hand side) equal to the values of the options at expiry. Probabilities of specific targets on FOMC meeting dates can be calculated from probabilities of the average funds rates over a month, as in (2).

Carlson, Craig, and Melick (2005) discuss in detail how the system can be estimated by ordinary least squares, imposing equality restrictions such as $\pi_{1}+\pi_{2}+\pi_{3}=1$. Alternatively, one can numerically maximize the likelihood function, under some assumption about the distribution of the error terms. Estimation by maximum likelihood permits more elaborate constraints, such as positive probabilities or requiring the probabilities to be consistent with the futures-implied rate.

As discussed earlier, Piazzesi and Swanson (2005) showed that, on average, federal funds

\footnotetext{
3 Notice that this estimation method assumes (counterfactually) that the options are European-that is, that they can be exercised only at maturity. The discrepancy introduced by this assumption is likely to be small, as the amount of early exercise of federal funds options is very small.
}

futures prices have implied interest rates that exceeded the actual realized federal funds rate. To adjust for this bias, the estimated probabilities can be constrained to imply a risk-adjusted target. However, because Piazzesi and Swanson's (2005) estimate of the risk premia may be too large, we adjust the federal funds futures-implied rate downward by 1 basis point for each month of the forecast horizon.

How should one interpret the error terms? The error terms result from market frictions such as (i) bid-ask spreads in both the option and the underlying asset, (ii) imperfect liquidity, and (iii) approximations in formulating the model, such as incorrect market risk premia, imposition of zero probabilities to unlikely actions, and ignoring the possibility of early exercise. In the absence of such approximations and frictions, the probabilities would be estimated exactly and the estimation would be an inversion of prices to probabilities. The facts that the errors are small and the probabilities are precisely estimated indicate that the approximations are probably reasonable and the frictions unimportant. 
Let's consider a concrete example. After the June 25, 2003, FOMC meeting, the federal funds target rate stood unchanged at 1 percent. What probabilities did the option market assign to various outcomes at the August 12, 2003, FOMC meeting? There were 13 options (seven calls and six puts) with eight different strike prices on June 25. The five possible targets that the Fed was likely to choose from were $0.5,0.75,1,1.25$, and 1.5. The following system is estimated by maximum likelihood:

\section{(4)}

$\left[\begin{array}{l}0.00250 \\ 0.00250 \\ 0.00501 \\ 0.02003 \\ 0.03506 \\ 0.05259 \\ 0.17280 \\ 0.14775 \\ 0.10017 \\ 0.05259 \\ 0.00751 \\ 0.00250 \\ 0.00250\end{array}\right]=\left[\begin{array}{ccccc}0.0101 & 0 & 0 & 0 & 0 \\ 0.0726 & 0 & 0 & 0 & 0 \\ 0.1351 & 0 & 0 & 0 & 0 \\ 0.1976 & 0.0363 & 0 & 0 & 0 \\ 0.2601 & 0.0988 & 0 & 0 & 0 \\ 0.3226 & 0.1613 & 0 & 0 & 0 \\ 0.4476 & 0.2863 & 0.1250 & 0 & 0 \\ 0 & 0.0262 & 0.1875 & 0.3488 & 0.5101 \\ 0 & 0 & 0.1250 & 0.2863 & 0.4476 \\ 0 & 0 & 0.0625 & 0.2238 & 0.3851 \\ 0 & 0 & 0 & 0.1613 & 0.3226 \\ 0 & 0 & 0 & 0.0363 & 0.1976 \\ 0 & 0 & 0 & 0 & 0.1351\end{array}\right]\left[\begin{array}{c}\pi_{0.5} \\ \pi_{0.75} \\ \pi_{1.0} \\ \pi_{1.25} \\ \pi_{1.5}\end{array}\right]+\varepsilon_{t}$,

where $\varepsilon_{t}$ is a 13-by-1 vector of normally distributed errors.

It is instructive to see how one transforms the market data to the data in (4). The first variable on the left-hand side (0.00250) is the price of the first call option, with a strike price of 99.3125 , evaluated at the expiration date of the option, in about 3 months $\left(e^{r(T-t)} C\left(t, T, X_{1}, F_{t}\right)\right)$, at an interest rate of 0.925 percent. The variable in the first row, first column, on the right-hand side is the payoff to a call option with a strike of 99.3125, assuming that the FOMC chooses a target rate of 0.5 percent on August 12. A target of 1.0 percent prior to August 12, combined with a move to 0.5 percent on August 12, would produce an average target rate of $0.6774(=1 * 11 / 31+0.5 * 20 / 31)$ during August, which translates into a final settlement price on the futures contract of $(100-0.6774=)$ 99.3226. If that 0.5 percent target were chosen, a call option with a strike of 99.3125 would be worth $(99.3226-99.3125=) 0.0101$, using the formula $\max \left(0, F_{T, 1}-X_{1}\right)$. Similarly, if one looks at the first row, second column, which assumes that the FOMC chooses a 0.75 percent target on August 12, the final settlement price for the futures contract would be $99.1613(=100-1.0 * 11 / 31-0.75$ * 20/31) and so a call option with a strike of 99.3125 would be worthless. That is, the term in the first row, second column of the right-hand side is 0 . Each column of the regressor matrix is associated with a unique FOMC target, and each row is associated with a unique option.

Estimating this system, subject to the following constraints that the probabilities are positive and sum to 1 and that the mean of the PDF equals the term premium-adjusted futures price, produces the following coefficients for the five elements of the $\pi$ vector: $\pi=\{0.114,0.188,0.697,0,0\}$. The standard errors for the estimated probabilities range from almost zero to 0.015 .

The estimation constrains the probabilities to generate the interest rate implied by the futures price, adjusted for risk. In the example, the futures price for August was 99.045, which implied an interest rate of 0.955 percent for August. Adjusting this implied interest rate for the 67-day forecast horizon-June 25 through August 31-and assuming 1 basis point every 30 days, one obtains a riskadjusted implied rate for August of (0.955 - (67/30) $* 0.01=$ ) 0.9327 . When numerically optimizing the likelihood function to calculate probabilities, one can force the implied interest rate to equal this risk-adjusted interest rate. In the present example, one can verify that the estimated probabilities imply a federal funds rate for August of 0.9327 percent. $^{4}$

To informally assess the importance of the constraints-the fit of the model-one can estimate the unconstrained model to see whether the results are sensitive to the imposition of the constraints. If the results are highly sensitive, it might suggest that the model doesn't fit the data well and the probabilities are not reliable. Reassuringly, the unconstrained system produces a plausible and roughly similar probability vector of $\pi=\{0.050,0.226,0.686,0.023,0.013\}$, whose standard errors are of similar magnitudes to those from the constrained system.

4 The federal funds rates implied by the five targets ( 0.5 to 1.5 percent) are $0.6774,0.8387,1,1.1613$, and 1.3226 . Thus, the expected funds rate is $0.9327(=0.6774 * 0.11439026+0.8387$ * $0.18845445+1 * 0.69715529+1.1613 * 0+1.3226 * 0)$. 
Finally, one might wonder whether a normal likelihood function for the errors is appropriate. The error terms, $\varepsilon_{i}$, cannot literally be normal, as unbounded support for $\varepsilon$ would be inconsistent with the requirement that option prices must be non-negative. To investigate whether the distributional assumption for $\varepsilon$ is important, we reestimated the example with a truncated normal distribution that required option prices be nonnegative. The truncated distribution produced comparable results with those from a normal distribution. The estimated probabilities for the five targets were $0.1057,0.2059,0.6884,0$, and 0 , respectively. The largest change in a probability estimate from the normal distribution was a very modest 1.7 percentage points.

\section{USING OPTIONS TO GAUGE MARKET UNCERTAINTY ABOUT FUTURE FEDERAL FUNDS TARGETS}

Even when the strategy driving monetary policy decisions is well understood and when the central bank seeks to operate in a transparent manner, market expectations can change when the policy strategy changes or when new information about economic conditions arrives. This section uses daily PDFs to explore the evolving uncertainty among market participants about future monetary policy actions.

\section{August 2003: FOMC Pre-Commits to Monetary Policy Accommodation for a "Considerable Period"}

By the fall of 2002, U.S. inflation was consistent with price stability as commonly understood today (i.e., inflation was of little consequence in making economic decisions). In fact, inflation had declined so much that the Federal Reserve began to consider further declines to be unwelcome because they might lead to deflation.

Financial analysts may have misinterpreted statements by Federal Reserve officials in the fall of 2002 and the spring of 2003 to imply that there would be a prolonged period of lower short-term rates and/or the purchase of long-term bonds by the Fed in order to implement "easier" monetary policy (Neely, 2004). Moreover, the FOMC statement of May 6, 2003, was widely misinterpreted to confirm such incorrect beliefs. ${ }^{5}$ Thus, by early June 2003, bond markets had come to expect lower interest rates for a longer period than may have been warranted by the state of the economy. Neely (2003) provides some evidence to suggest that these developments were related to expectations of lower real growth, rather than lower inflation.

The top panel of Figure 3 shows that, in the days prior to the June 25, 2003, FOMC meeting, investors perceived a 50 to 70 percent chance that the target rate would be lowered from 1.25 percent to 0.75 percent. This is indicated by the thick, light-blue line in the top panel of the figure, which plots the daily implied probability estimates associated with each possible target rate.

The FOMC, in fact, decided to cut the target rate only from 1.25 percent to 1.00 percent. This action not only resolved the near-term uncertainty investors faced, but also caused them to revise their expectations for future monetary policy. The second panel of Figure 3 shows that expectations during July of further rate cuts at the August meeting rapidly declined. The two lines showing the probabilities assigned by investors to a 0.75 percent target and to a 0.50 percent target after the August meeting converged toward zero as July passed. By late July, markets were fairly certain that the FOMC would choose a 1 percent target at the August meeting.

The third panel of Figure 3 shows the analogous probabilities of various target outcomes for the December 2003 meeting, as assessed each day from June onward. This panel shows that by late July or early August, markets had started to assign positive probabilities to the possibility of an increase to 1.25 or 1.50 percent at the December meeting.

To reassure markets that the target rate would not be raised in the near future, the FOMC issued a statement after the August 12, 2003, meeting

\footnotetext{
5 The May 6, 2003, statement contained the following sentence: "The probability of an unwelcome substantial fall in inflation, though minor, exceeds that of a pickup in inflation from its already low level"; www.federalreserve.gov/boarddocs/press/monetary/ 2003/20030506/default.htm.
} 
Figure 3

Option-Implied Probabilities of Federal Funds Target Rates To Be Chosen at the June, August, and December 2003 Meetings
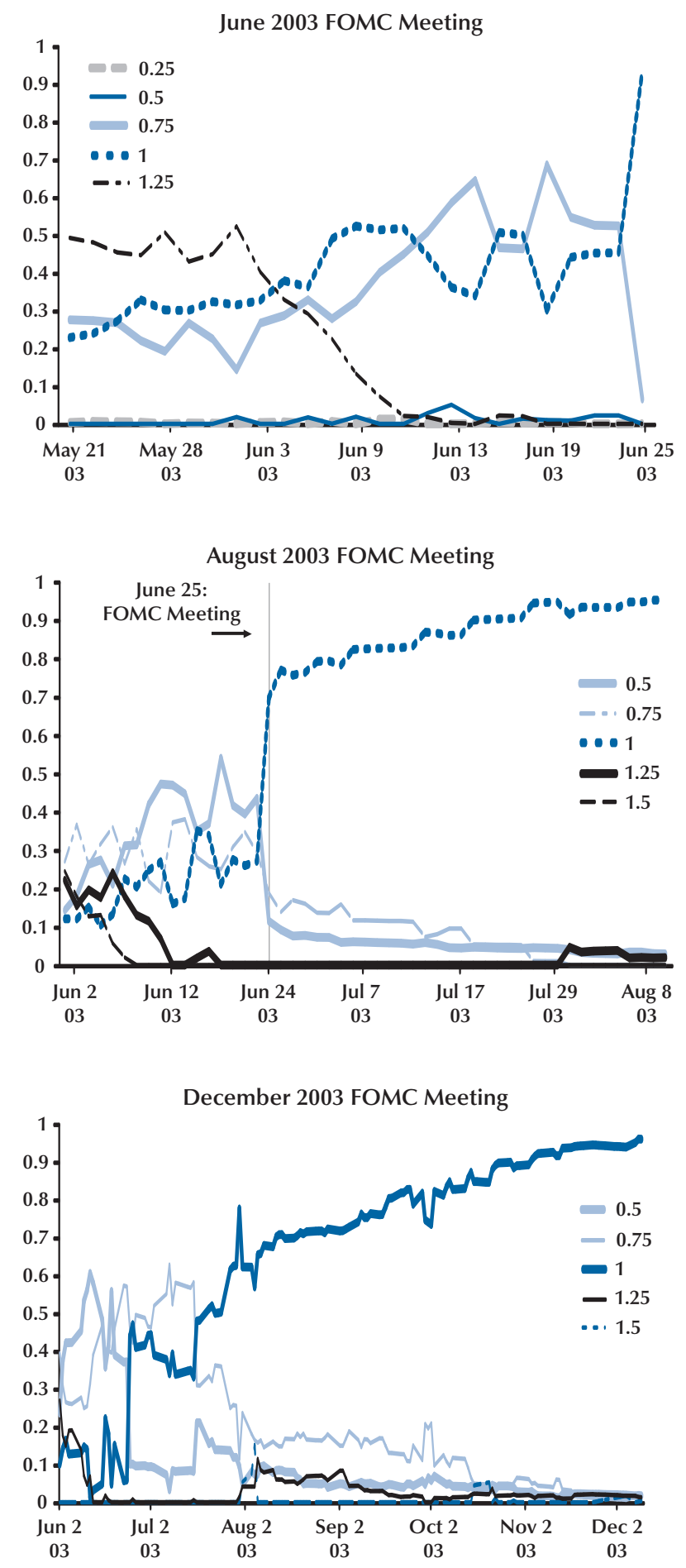
that contained the first commitment by the FOMC that the current low target rate would persist: "The Committee judges that, on balance, the risk of inflation becoming undesirably low is likely to be the predominant concern for the foreseeable future. In these circumstances, the Committee believes that policy accommodation can be maintained for a considerable period." 6 This language was repeated in the September 16, 2003, FOMC statement. The bottom panel of Figure 3 illustrates that, in the 3 months after August 12, market expectations coalesced on the idea that a 1 percent target would be the outcome of the December meeting. The FOMC announcements successfully anchored market expectations on a 1 percent funds target rate for at least the next 4 months.

\section{May 2004: FOMC Signals Its First Rate Increase in Four Years}

The Federal Reserve never defined what a "considerable period" was, but no one doubted that the FOMC's target rate would be raised eventually. From Figure 4 it appears that speculation about impending rate increases began in earnest in March 2004 and that expectations about the timing and magnitude of rate increases evolved considerably during the course of the year.

Figure 4 displays a term structure of expected target rates extracted from 1-, 3-, 6- and 9-monthahead federal funds futures contracts on each trading day during 2004. The fixed calendarmonth nature of federal funds futures contracts means that the "roll forward" day occurs on the first trading day of each month. For example, on May 28, 2004, the expected average funds rate for "next month" referred to the average for June 2004 and was 1.02 percent. $^{7}$ The next business day was June 1, when the May contract was settled and "next month" became July 2004. The thin line representing the 1-month-ahead expected federal funds rate shows a jump to 1.23 percent on June 1,

6 Press release issued by the Federal Reserve's FOMC, August 12, 2003; www.federalreserve.gov/boarddocs/press/monetary/2003/ $20030812 /$.

7 The average effective rate can deviate slightly from the FOMC's target rate because of daily fluctuations in actual reserve-market conditions. implying that market expectations for a 25-basispoint increase by "next month"-effectively, by the end of June-was considered very likely.

Figure 4 allows us to pinpoint evolving market expectations about the timing of the first target increase in four years. The line representing 9month-ahead expectations shows that, during January and February 2004, market expectations were for a funds target in the 1.25 to 1.50 percent range during October and November 2004. But when would these increases occur? The line representing 3-month-ahead expectations jumped abruptly on May 3, 2004, from 1.11 percent to 1.27 percent. This coincided with the roll-forward from July to August 2004 of the 3-month-ahead contract. The jump implies that market expectations at that time (May 3) were tilted toward an initial increase in the funds target at the August 10 meeting, rather than at the June 29-30 meeting. Only later during May 2004 did expectations shift toward an initial increase at the June meeting, as described above in the context of the 1month-ahead contract.

The distance between the 1-, 3-, 6- and 9month-ahead implied yields in the figure illustrates the expected pace of funds target increases at any given point in time. On June 14, 2004, for example, the market expected the funds target to average 1.33 percent during July 2004 (next month), 1.85 percent during September 2004 (3 months ahead), 2.44 percent during December 2004 (6 months ahead), and 2.95 percent during March 2005 (9 months ahead). In the event, the actual average effective funds rates during those months were 1.26, 1.61, 2.16, and 2.63 percent, respectively.

Given the difficulty of separating the timing from the magnitude of future rate increases from federal funds futures alone, it is helpful to examine risk-neutral PDFs derived from federal funds futures options. The top panel of Figure 5 displays the evolving probabilities attached to various possible rate targets to be chosen at the June 2004 FOMC meeting. While Figure 4 demonstrates that market expectations of a sequence of future rate increases emerged after the May 4, 2004, FOMC meeting, the top panel of Figure 5 shows that, in early summer of 2004, market participants became 


\section{Figure 4}

\section{Federal Funds Futures-Implied Yields from Contracts Traded in 2004}

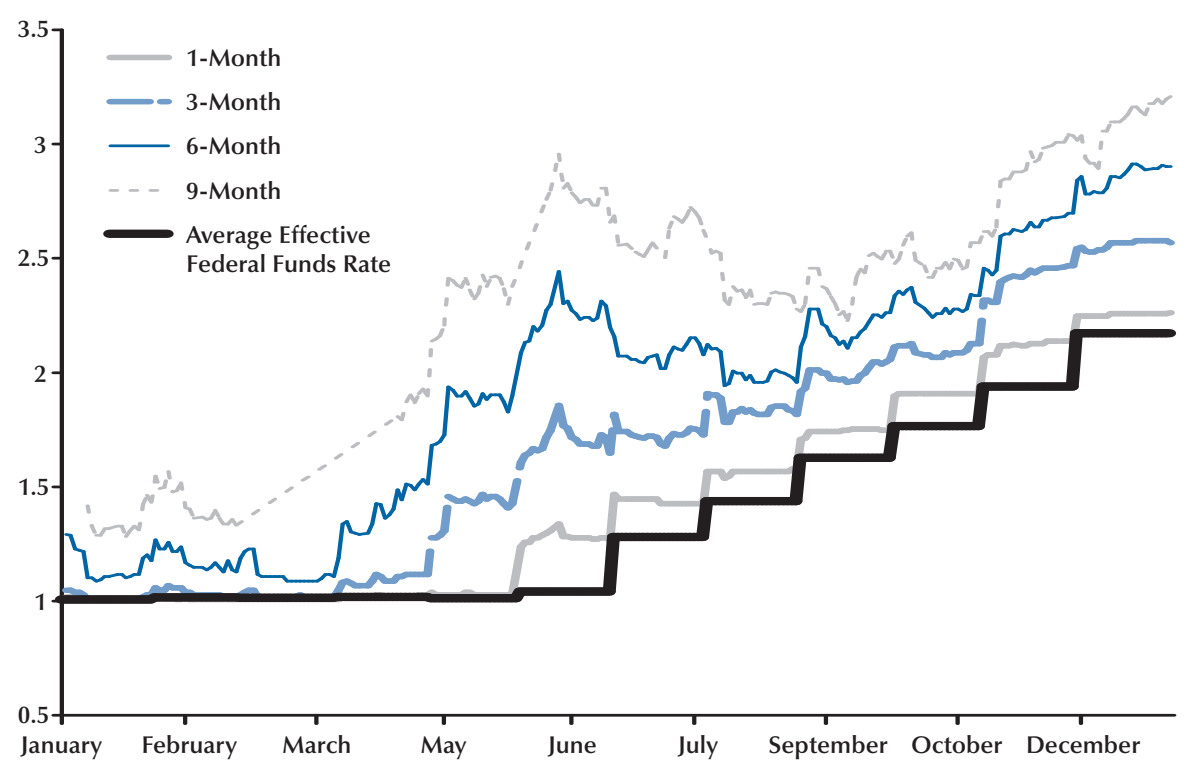

NOTE: The figure shows the average federal funds rates implied by the 1-, 3-, 6-, and 9-month-ahead federal funds rate futures contracts for 2004 .

convinced that the rate increases were to start with the June FOMC meeting. The bottom panel of Figure 5 shows that the FOMC's June 30 decision to raise the funds target from 1.00 percent to 1.25 percent prompted agents to expect further increases at the August meeting.

\section{June 2004: FOMC Pre-Commits to Increasing Its Target Rate at a "Measured Pace"}

Apparently wary of disrupting financial markets with rapid rate increases, the FOMC signaled after its June 30, 2004, meeting that it intended to raise its target rate gradually over time: "With underlying inflation still expected to be relatively low, the Committee believes that policy accommodation can be removed at a pace that is likely to be measured. Nonetheless, the Committee will respond to changes in economic prospects as needed to fulfill its obligation to maintain price stability."8 Figure 4 shows that, after the FOMC's June 30 statement, with the target rate at 1.25 percent, expectations of longer-term increases moderated and stabilized. That is, the level and volatility of the 3-, 6-, and 9-month-ahead implied rates declined and stabilized after June 30 . This suggests that the "measured pace" language was well-understood by market participants.

The bottom panel of Figure 5 confirms this view by showing probabilities of targets to be chosen at the August 2004 FOMC meeting. Prior to the June 2004 FOMC meeting there were substantial expectations of a 50- or even 75-basispoint increase, to 1.75 or 2.0 percent at the August meeting. But after the statement at the June FOMC meeting, the market gradually became convinced that the increase was going to be in increments of 25 basis points, to 1.5 percent at the August 2004 meeting.

8 Press release issued by the Federal Reserve's FOMC, June 30, 2004; www.federalreserve.gov/boarddocs/press/monetary/2004/ 20040630/default.htm. 
Figure 5

Option-Implied Probabilities of Federal Funds Target Rates To Be Chosen at the June and August 2004 FOMC Meeting
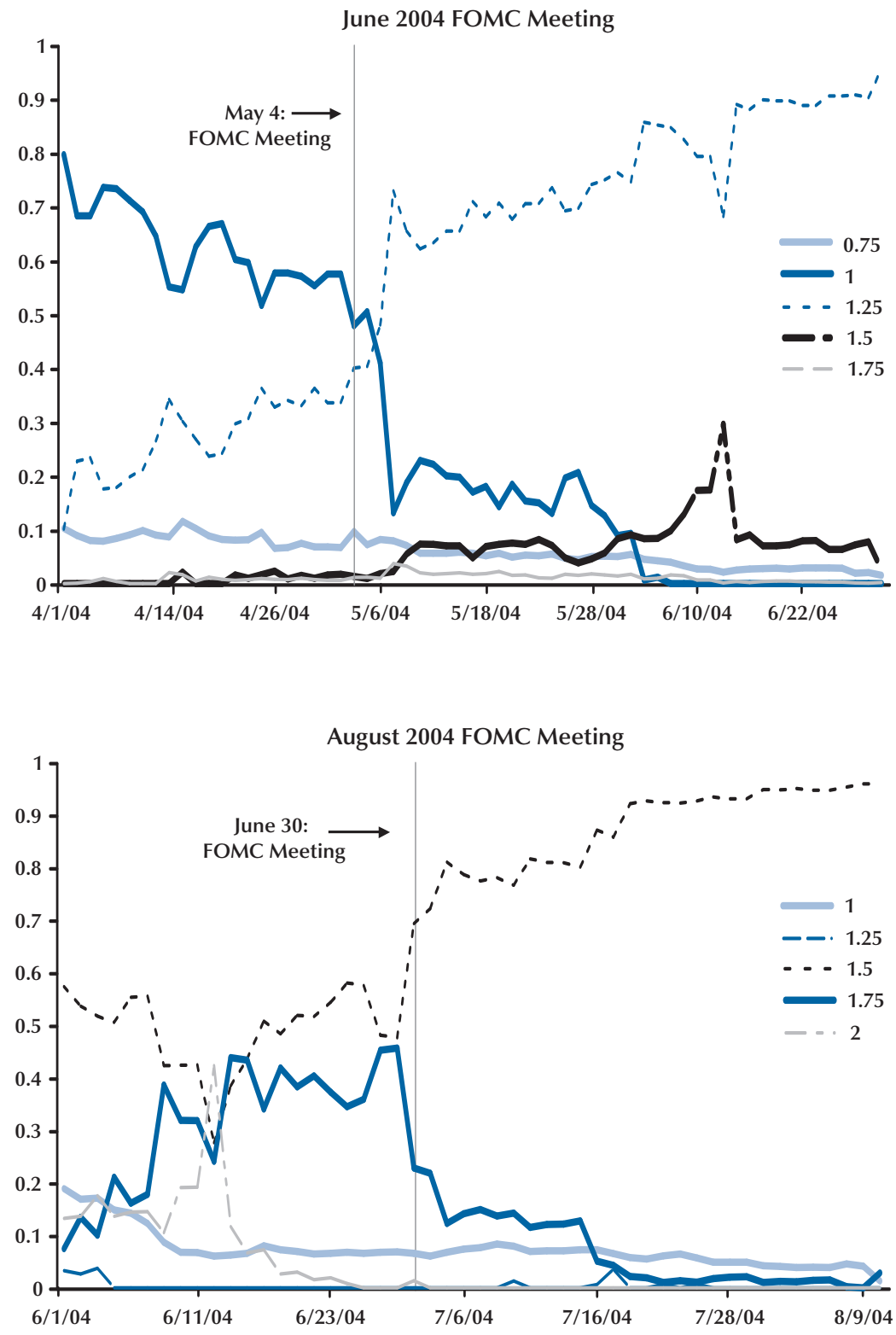


\section{Figure 6}

\section{Federal Funds Futures-Implied Yields from Contracts Traded in 2005}

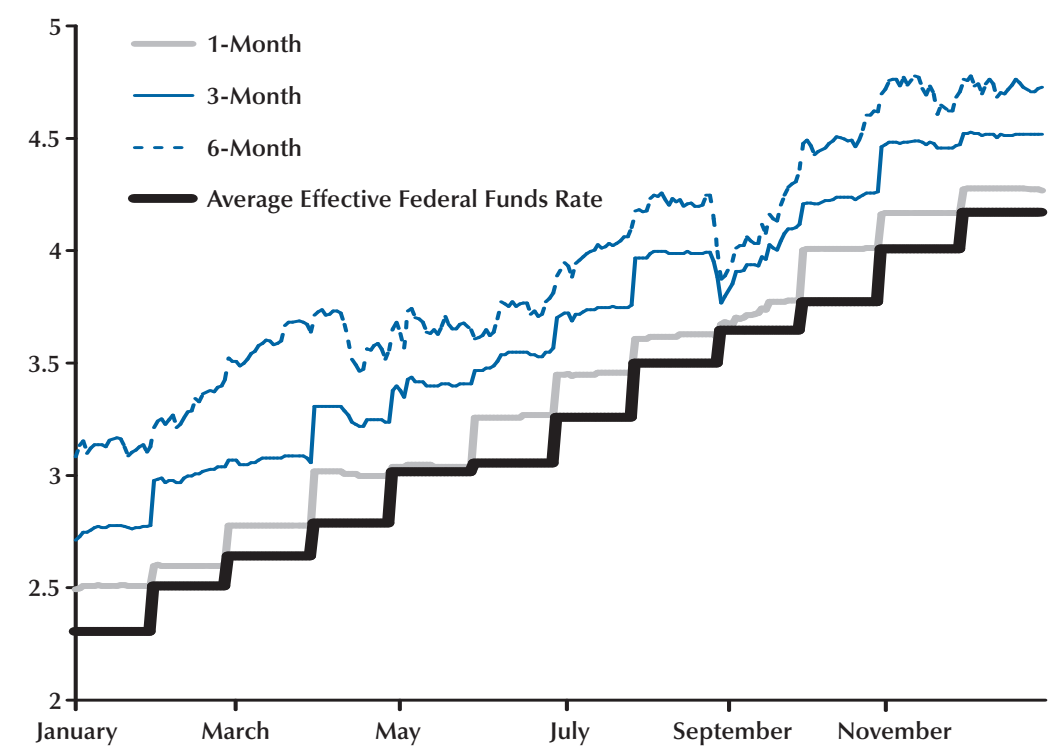

NOTE: The figure shows the average federal funds rates implied by the 1-, 3-, 6-, and 9-month-ahead federal funds rate futures contracts for 2005.

\section{August/September 2005: Gulf Coast Hurricanes Create Uncertainty About the FOMC's Likely Rate Increases}

The devastation along the Gulf Coast caused by hurricanes Katrina and Rita in August and September 2005 substantially revised market expectations about monetary policy actions. Figure 6 displays the federal funds futures-implied target rates derived from 1-, 3-, and 6-month-ahead futures contracts traded in 2005. The impact of the hurricanes, especially Katrina, is clearly visible about September 1, 2005. Fearing that Katrina might significantly slow the U.S. economy, market participants revised down their expectations of 3- and 6-month-ahead target rates.

One also can examine the PDFs from option prices before and after Katrina's second landfall (near New Orleans, after traversing the southern tip of Florida) on August 29 to infer the evolution of expectations for the November 1, 2005, FOMC meeting over this turbulent period. The upper left panel of Figure 7 shows that, on August 23-when the funds target was 3.5 percent- the markets expected a greater-than-80 percent chance of a 4.0 point target rate at the November 1 meeting, with some modest chance of a 3.75 or 4.25 percent target. On September 1, three days after Katrina made second landfall, market expectations of the funds target on November 1 had declined and dispersed significantly (top right subpanel). The mean futures rate was 3.74 percent, and the chances of a funds target of $3.5,3.75$, or 4.0 percent were approximately 38,31 , and 28 percent, respectively. In other words, the markets assessed the probability that the target at the November meeting would be 4.0 percent or greater declined from about 90 percent to about 30 percent.

By September 8, panic had subsided a bit; the bottom-left subpanel shows that the implied probabilities of 3.75 and 4.0 percent targets were 48 percent and 42 percent, respectively (bottomleft subpanel). Finally, by September 30-after a 


\section{Figure 7}

\section{Option-Derived Probability Density Functions (PDF) Surrounding Hurricane Katrina}
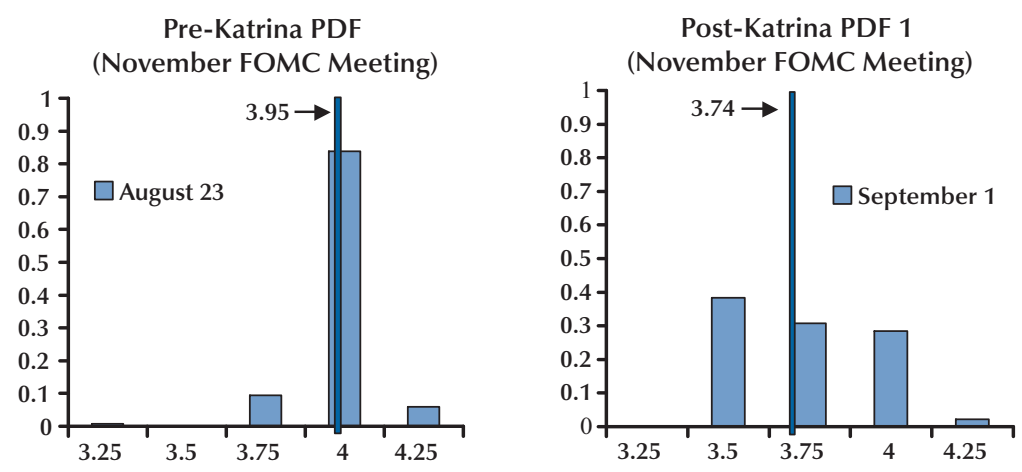

Post-Katrina PDF 2 (November FOMC Meeting)
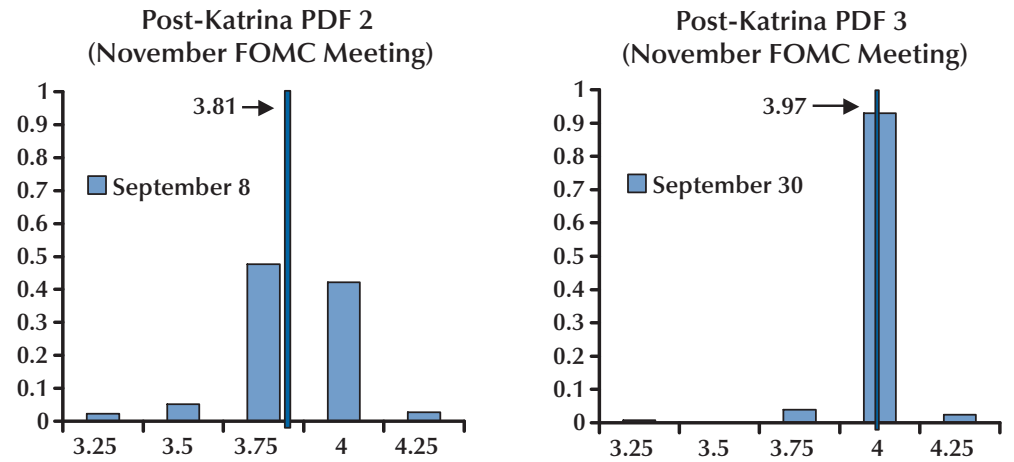

NOTE: The figure shows option-implied probability density functions around the time of Hurricane Katrina, which made second landfall on August 29, 2005. The vertical bars denote the rate implied by the federal funds futures contract price.

25-basis-point target increase to 3.75 percent at the September 20 FOMC meeting-the PDF showed that market expectations had returned to approximately the pre-Katrina level, with a more-than-90 percent chance of a 4.0 target at the November meeting (bottom-right subpanel).

Figure 8 shows another way of looking at the same information; it plots the probabilities of various outcomes at the November meeting over time. Four days after Katrina made landfall, the possibility that the Fed would increase the funds rate all the way to 4.0 percent by November 1 declined significantly, from 85 percent to 25 percent. At the same time, the possibility that the FOMC would not change the funds target at all increased to almost 30 percent for a day.

\section{April 27, 2006: Chairman Bernanke Testifies Before the Joint Economic Committee}

The weeks prior to the May 10, 2006, FOMC meeting were unusually active ones in the federal funds futures and options markets. Market expectations were quite sensitive to incoming economic data and statements. For example, the top panel of Figure 9 shows that strong reports on housing and durable goods on April 25 and 26 raised the expected federal funds rate from 5.11 percent to 5.16 percent and the lower panel shows that the implied probability of a 5.25 percent target rate after the June FOMC meeting rose from under 40 percent to about 60 percent. 


\section{Figure 8}

\section{Option-Implied Probabilities of Federal Funds Target Rates To Be Chosen at the November 2005 FOMC Meeting}

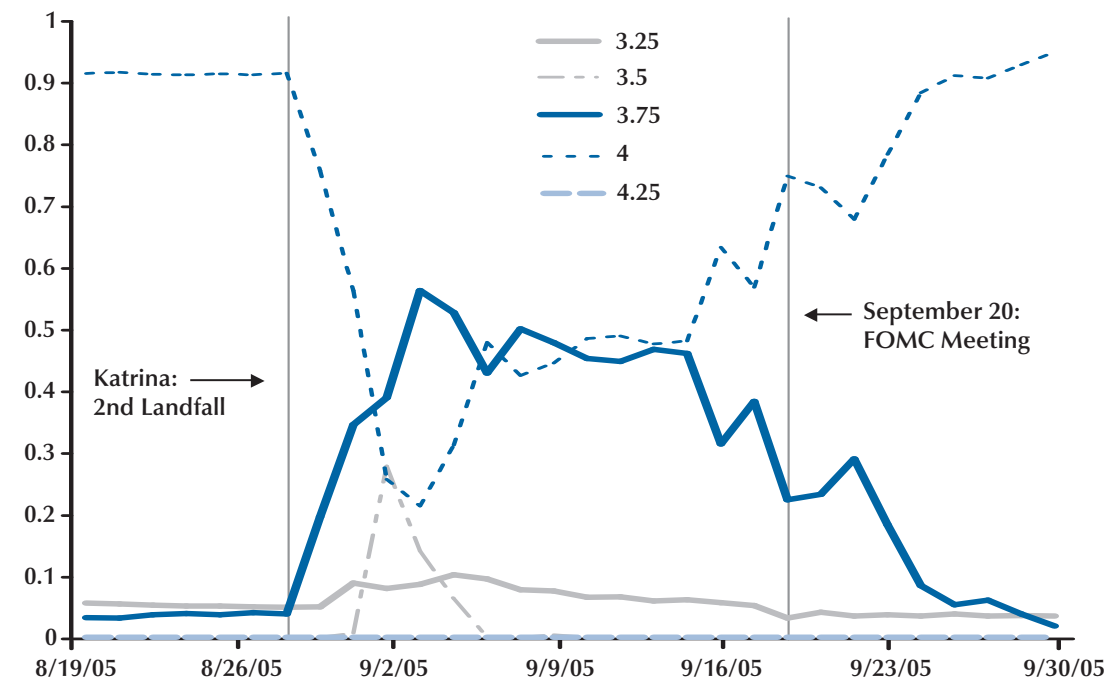

On April 27, Chairman Bernanke (2006) spoke before the Joint Economic Committee of Congress on the outlook for the U.S. economy. The Chairman was broadly optimistic about the state of the U.S. economy, describing the prospects for maintaining solid growth as "good" and the outlook for inflation as "reasonably favorable." The Chairman went on to note that the FOMC had increased the federal funds rate by 25 basis points at each of its previous 15 meetings and that the current federal funds target was 4.75 percent. The Chairman cautioned that

[P]olicy will respond to arriving information that affects the Committee's assessment of the medium-term risks to its objectives of price stability and maximum sustainable employment...[A]t some point in the future the Committee may decide to take no action at one or more meetings in the interest of allowing more time to receive information relevant to the outlook. Of course, a decision to take no action at a particular meeting does not preclude actions at subsequent meetings, and the Committee will not hesitate to act when it determines that doing so is needed to foster the achievement of the Federal Reserve's mandated objectives.

Economists might interpret such a comment as a judicious statement of the obvious: The FOMC's policy decisions will respond to news and changing economic conditions. It was widely reported that financial markets interpreted the statement to mean that a pause in the interest rate increases was imminent. Equity markets rallied; the S\&P 500 finished up over 4 points on April 27. The top panel of Figure 9 shows that the expected federal funds target for the May FOMC meeting fell from 5.16 percent to 5.07 percent between April 26 and April 28 in response to the Chairman's testimony. The lower panel shows that this was generated by a shift in the probability of a 5.25 percent target from 60 percent to 23 percent and a similar rise in the probability of a 5.0 percent target.

\section{SUMMARY}

This article uses the method of Carlson, Craig, and Melick (2005) to extract an implied risk- 
Figure 9

Expected Federal Funds Targets and Option-Implied Probabilities of Federal Funds Target Rates To Be Chosen at the May 2006 FOMC Meeting

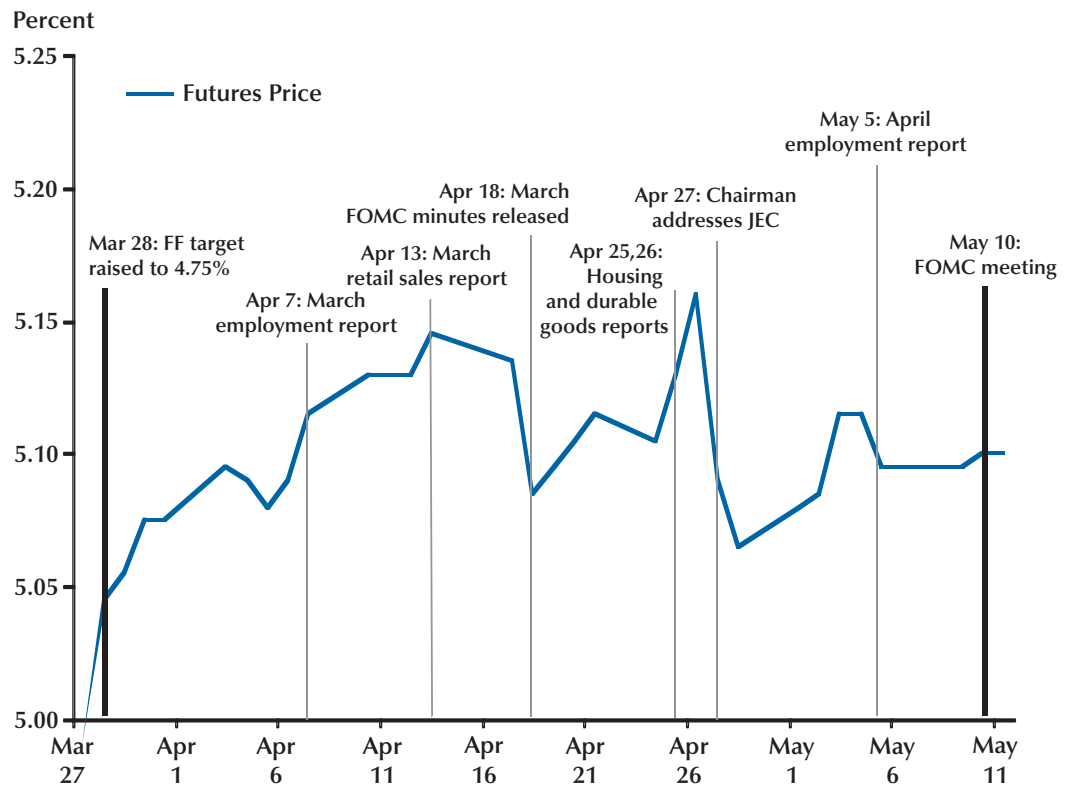

Probability of Various FF Targets after June 28-29 FOMC Meeting

Implied Probability

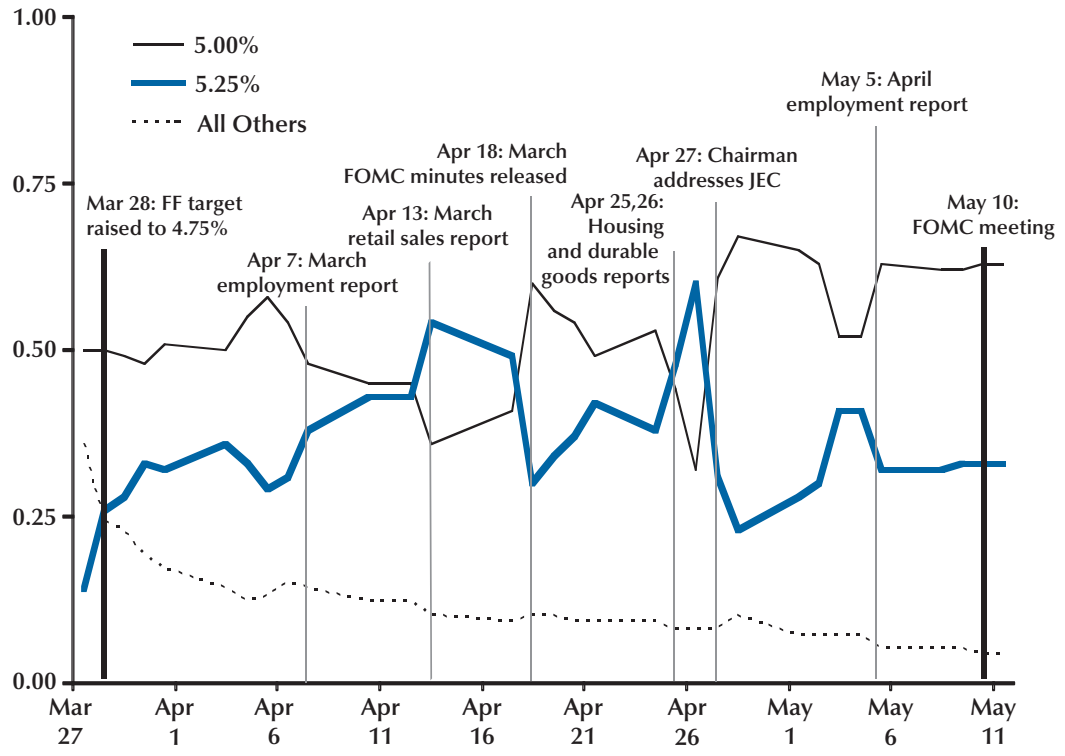

NOTE: FF, Federal funds; JEC, Joint Economic Committee. 
neutral probability density function over possible future federal funds target rates from daily option prices. Option-based forecasts are most useful when more than two federal funds target outcomes are plausible at an upcoming FOMC meeting. If only one or two meeting outcomes are plausible, a futures-based forecast is simpler and more appropriate.

We assess evolving market uncertainty about Federal Reserve monetary policy actions in a variety of recent events and episodes, including (i) a commitment by the FOMC to maintain monetary policy accommodation for a "considerable period"; (ii) a signal by the FOMC that the first target-rate increase in four years was forthcoming; (iii) a commitment by the FOMC to raise the target rate over time at a "measured pace"; (iv) the devastating aftermath of Hurricane Katrina; and (v) April 2006 testimony by Chairman Bernanke before the Joint Economic Committee. These episodes illustrate how federal funds futures options can be used to supplement the information derived from federal funds futures and other sources of market expectations about Federal Reserve monetary policy actions.

\section{REFERENCES}

Abken, Peter A. "Using Eurodollar Futures Options: Gauging the Market's View of Interest Rate Movements." Federal Reserve Bank of Atlanta Economic Review, 1995, 80(2), pp. 10-30.

Andersen, Allan B. and Wagener, Tom. "Extracting Risk Neutral Probability Densities by Fitting Implied Volatility Smiles: Some Methodological Points and an Application to the Three-Month Euribor Futures Option Prices.” Working Paper 198, European Central Bank, December 2002.

Bernanke, Ben S. "Outlook for the U.S. Economy." Testimony Before the U.S. Congress, Joint Economic Committee, April 27, 2006; www.federalreserve.gov/boarddocs/testimony/2006.

Bliss, Robert R. and Panigirtzoglou, Nikolaos.

"Testing the Stability of Implied Probability Density
Functions." Journal of Banking and Finance, March 2002, 26(2-3), pp. 381-422.

Carlson, John B.; Craig, Ben R. and Melick, William R. "Recovering Market Expectations of FOMC Rate Changes with Options on Federal Funds Futures." Journal of Futures Markets, December 2005, 25(12), pp. 1203-42.

Hordahl, Peter and Vestin, David. "Interpreting Implied Risk-Neutral Densities: The Role of Risk Premia." Review of Finance, 2005, 9(1), pp. 97-137.

Neely, Christopher J. "Bond Market Mania.” Federal Reserve Bank of St. Louis Monetary Trends, October 2003.

Neely, Christopher J. "Miscommunication Shook Up Mortgage, Bond Markets." Federal Reserve Bank of St. Louis Regional Economist, April 2004, pp. 4-9.

Neely, Christopher J. "Using Implied Volatility to Measure Uncertainty About Interest Rates.” Federal Reserve Bank of St. Louis Review, May/June 2005, 87(3), pp. 407-25.

Piazzesi, Monika and Swanson, Eric. "Futures Prices as Risk-Adjusted Forecasts of Monetary Policy.” NBER Working Paper 10547, National Bureau of Economic Research, 2005; www.nber.org/papers/w10547.

Poole, William; Rasche, Robert G. and Thornton, Daniel L. "Market Anticipations of Monetary Policy Actions." Federal Reserve Bank of St. Louis Review, July/August 2002, 84(2), pp. 65-93.

Sack, Brian. "Extracting the Expected Path of Monetary Policy from Futures Rates." Journal of Futures Markets, August 2004, 24(8), pp. 733-54.

Sarno, Lucio; Thornton, Daniel L. and Valente, Giorgio. "Federal Funds Rate Prediction." Journal of Money, Credit, and Banking, June 2005, 37(3), pp. 449-71.

Soderlind, Paul and Svensson, Lars E.O. "New Techniques to Extract Market Expectations from Financial Instruments." Journal of Monetary Economics, October 1997, 40(2), pp. 383-429. 
